\section{Kazakhstan, tourism}

João Sarmento ${ }^{1,2}$ and

Askar Mukashev Serikboluly ${ }^{3}$

${ }^{1}$ University of Minho, Guimarães, Portugal

${ }^{2}$ University of Lisbon, Lisbon, Portugal

${ }^{3}$ AEO, Nazarbayev Intellectual Schools, Astana, Kazakhstan

Kazakhstan is the ninth largest country in the world (2.7 million $\mathrm{km}^{2}$ ). Located in Central Asia (Figure 1), with a population of 16.57 million (2011 census), it is bordered by $>$ Russia, - Uzbekistan, Kyrgyzstan, Turkmenistan, and $>$ China. Its economy is heavily dependent on the oil sector (over $11 \%$ GDP and nearly $57 \%$ of total exports in 2010) and on uranium, textiles, wheat, and livestock (Gleason 2003).

During Soviet times (1922-1991), the economy was centrally planned (Jeffries 2003), and > social tourism was promoted. Since its independence in 1991 and during the transition to a market economy in 2000, tourism $>$ development was unplanned. A first 5-year strategic plan was published in 2000, with a new Ministry of Tourism and Sport established in 2006. Research on $>$ national tourism and on the position of Kazakhstan in the world tourism market was conducted during 2005-2007. The 2007-2011 tourism development program supported an increase in public funding, participation in international exhibitions and fairs,
- attraction of foreign investment, international advertising, and the hosting of the VII Asian Winter Games in 2011.

In the same year, Kazakhstan had four million international arrivals, an increase of $20 \%$ from 2010 (UNWTO 2012). Reflecting sustained per capita growth and an emphasis on social welfare and security, the number of domestic tourists rose by $10.3 \%$ to 4.5 million in the same period. Tourism's contribution to GDP was $5.2 \%$ in 2012 (WTTC 2013). Income from tourism increased by $56 \%$ to $\$ 1.2$ billion and investments also grew by $58.3 \%$. From 2006 to 2012, the number of tourism jobs $(393,000$ or $4.7 \%$ of total employment) expanded considerably. The country's vast natural landscapes containing steppes and mountains, together with its nomadic people, are its main appeals. The two main urban attractions are the former capital Almaty and the present futuristic capital Astana. Despite oil revenues tourism $>$ infrastructure is poor.

The Ministry of Tourism and Sport was reorganized in 2012, with its tourism functions now housed in the Ministry of $>$ Industry and New Technologies. A $>$ tourist cluster is being established along the "Western Europe-Western China" corridor. Five tourism megaprojects are also underway. A collaborative government initiative will enhance $>$ sustainable tourism development along the historic Silk Road route. The government has implemented professional $>$ certification for tourism offered in more than 30 institutions. Ten universities have postgraduate 


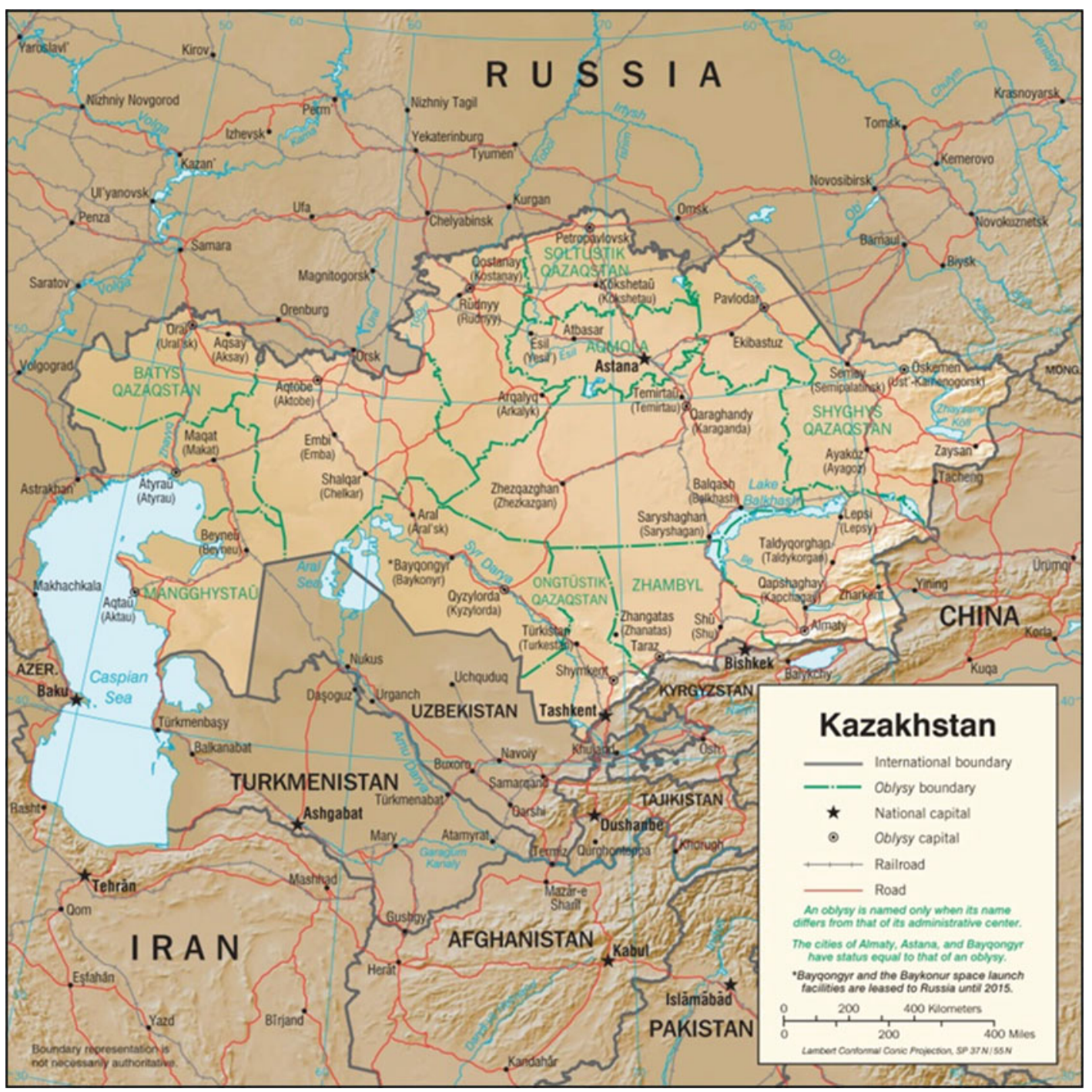

Kazakhstan, tourism, Figure 1 Map of Kazakhstan

tourism degrees. One bachelor degree program has the $>$ UNWTO.TedQual accreditation.

$\checkmark$ Future tourism $>$ facilitation measures include easier $>$ visa procedures, a Central Asia visa-free zone, and reduction of $>$ transportation prices. Potential attractions include $\triangleright$ space tourism at the Baikonur Cosmodrome, $>$ dark tourism based on the Stalin-era camps around Karaganda, and event tourism.

See also $\triangleright$ Dark tourism, $\triangleright$ ethnicity, $\triangleright$ mass tourism, $\triangleright$ space tourism, $\triangleright$ sustainable tourism.

\section{References}

Gleason, G. 2003 Markets and Politics in Central Asia. New York: Routledge.

Jeffries, I. 2003 The Caucasus and Central Asian Republics at the Turn of the Twenty-First Century. New York: Routledge.

UNWTO 2012 Tourism Highlights. Madrid: World Tourism Organization.

WTTC 2013 Travel and Tourism. Economic Impact 2013. London: World Travel and Tourism Council. 